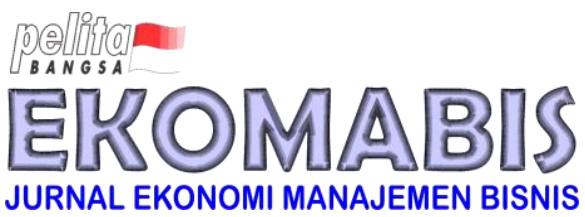

\title{
Peran Kepemimpinan Transformasional dan Kepuasan Kerja terhadap Niat untuk Tinggal dengan Keterikatan Kerja sebagai Mediasi
}

\section{(The Role of Transformational Leadership and Job Satisfaction on Intention to Stay with Job Engagement as Mediation)}

\section{Yuhaning Praborini1; Thoha Asaroni2; Mohamad Naim ${ }^{3}$; Youdho Febriano $^{4}$}

\begin{abstract}
Abstrak
Niat untuk tinggal di dalam perusahaan dipengaruhi oleh beberapa faktor diantaranya kepemimpinan transformasional dan kepuasan kerja. Kepemimpinan yang baik dan ada nya kepuasan karyawan akan meningkatkan keinginan untuk tinggal didalam perusahaan, dan hal tersebut akan diperkuat dengan adanya keterikatan terhadap pekerjaan. Penelitian ini untuk mengetahui pengaruh kepemimpinan transformasional dan kepuasan kerja yang dimediasi oleh keterikatan kerja terhadap niat untuk tinggal. Penelitian menggunakan pendekatan kuantitatif dengan sampel karyawan PT. AW Indonesia di Cikarang sebanyak 55 orang. Analisis menggunakan model struktural diolah software SMARTPLS 3.0. Hasil penelitian ini terdapat pengaruh tidak langsung antara variabel Kepemimpinan Transformasional, Kepuasan Kerja, Keterikatan kerja terhadap Niat untuk Tinggal.

Kata Kunci: Kepemimpinan Transformasional, Kepuasan, Keterikatan, Niat untuk Tinggal
\end{abstract}

\begin{abstract} Satisfaction, Work Attachment to the Intention to Stay.

Keywords: Transformational Leadership, Satisfaction, Engagement, Intention to Stay Kode JEL:

\footnotetext{
1 "Prodi Magister Manajemen Universitas Pelita Bangsa"; yuhaning1010@gmail.com

2 "Prodi Magister Manajemen Universitas Pelita Bangsa"; asaroni75@gmail.com

3 "Prodi Magister Manajemen Universitas Pelita Bangsa"; gununglano728@gmail.com

4 "Prodi Magister Manajemen Universitas Pelita Bangsa"; youdhofebriano@gmail.com
}

The intention to stay in the company is influenced by several factors including transformational leadership and job satisfaction. Good leadership and employee satisfaction will increase the desire to stay in the company, and it will be strengthened by an attachment to the job. This research is to find out the effect of transformational leadership and job satisfaction mediated by work attachment to the intention to stay. The research used a quantitative approach with a sample of 55 employees of PT AW Indonesia in Cikarang. Analysis using structural models processed SMARTPLS 3.0 software. The results of this study have an indirect influence between the variables of Transformational Leadership, Job 


\section{Pendahuluan}

Didalam suatu perusahaan dibutuhkan SDM yang berkualitas dan berkompeten untuk menunjang keberhasilan suatu perusahaan. Ini sangat dibutuhkan ditengah - tengah persaingan industri yang berkembang pesat. SDM yang kuat dan berkomitmen dapat menjadi cerminan kekuatan suatu perusahaan, selain itu karyawan sebagai aset penting yang membedakan perusahaan satu dengan yang lainnya. Kualitas karyawan menjadi keunggulan kompetitif perusahaan dan akan meningkatkan tujuan perusahaan (Kemie \& Purba, 2019). Perusahaan untuk mempertahankan karyawan yang unggul tidak selalu mudah, seringkali karyawan merasa tidak puas dan berakhir dengan pengunduran diri. Bagi perusahaan, dengan adanya karyawan yang mengundurkan menjadi masalah serius dan perlu ditangani sesegera mungkin dengan baik karena akan berdampak pada penurunan produktivitas perusahaan. Karyawan yang cenderung merasa tidak puas dan memiliki keinginan untuk mengundurkan diri dari perusahaan ini menyisakan satu permasalahan sendiri bagi perusahaan terutama untuk karyawan yang memiliki kompetensi dan kemampuan yang unggul. Untuk itu perusahaan perlu menggali faktor - faktor apa saja yang mempengaruhi karyawan tidak bertahan lama (intention to stay), keinginan karyawan untuk berpindah kerja masih pada tahap niat (intention to stay) dapat kita cegah. Beberapa faktor munculnya intention to stay adalah pengembangan karir, kepuasan kerja, keterikatan kerja, kepemimpinan, remunerasi (gaji), budaya organisasi dan karakteristik pekerja (Kriswanta et al., 2021).

Keinginan untuk tinggal (intention to stay) karyawan dalam suatu perusahaan sangat penting dalam perannya untuk kelangsungan suatu perusahaan. Niat untuk tinggal ini dapaf didefinisikan sikap yang ditunjukkan dari karyawan untuk terikat dan bertahan pada perusahaan tempat bekerja dalam jangka waktu lama meskipun ada tawaran menarik di tempat lain (Kemie \& Purba, 2019). Niat untuk tinggal (intention to stay) mencerminkan komitmen dan kemauan tetap bekerja dari seorang karyawan di organisasi. Keinginan tinggal dipengaruhi berbagai hal seperti karakteristik personal, peran karyawan organisasi, fasilitas perusahaan, peluang perputaran karyawan dan pekerjaan (Surantoro \& Riyadus Solichin, 2020). Ada lima alasan yang membuat karyawan memiliki intention to stay, yaitu: kebanggaan pada organisasi, atasan (supervisor) yang kompeten, kompensasi adil dan menarik, budaya menghargai dan menghormati, serta pekerjaan yang menarik dan berarti (Kemei dan Purba, 2019).

Kepemimpinan yang baik atau bisa mendengarkan dan memahami bawahannya akan membuat karyawan tetap tinggal di perusahaan. Pemimpin yang membuat keputusan atas kesepakatan bersama serta bertindak adil dan arif dalam pengambilan kebijakan akan membuat karyawan nyaman dan betah (Ghoniyah, 2011). Bentuk kepemimpinan yang dimiliki pemimpin juga memiliki andil yang besar. Kepemimpinan transformasional salah satunya dapat diterapkan dengan memberikan kesempatan karyawan mengekspresikan opini (Rokhman, 2011). Pemimpin transformasional dapat memotivasi bawahan untuk bekerja demi mencapai sasaran organisasi sekaligus memuaskan kebutuhan diri karyawan (Maulizar, 2012). Namun pada penelitian sebelumnya terdapat temuan bahwa kepemimpinan tidak mempengaruhi niat untuk tinggal karyawan di dalam perusahaan (Kriswanta et al., 2021). Untuk itu perlu dilihat faktor apa saja yang dapat memediasi antara kepemimpinan transformasional terhadap niat untuk tinggal, di dalam perusahaan kepemimpinan dapat menimbulkan kenyamanan dalam bekerja sehingga dengan adanya kenyamanan tersebut akan menumbuhkan rasa keterikatan dalam bekerja. Dengan semakin terikatnya karyawan 
terhadap pekerjaan akan semakin meningkatkan niat untuk tinggal didalam perusahaan.

Keterikatan karyawan terhadap perusahan ditunjukkan dengan sikap karyawan dalam bekerja, sikap karyawan ini tidak semata - mata bekerja karena rutinitas pekerjaan tetapi bekerja dengan bangga dan senang terhadap lingkungan kerjanya. Karyawan yang terikat akan pekerjaannya akan terlibat sepenuhnya didalam perusahaan. Dan salah satu faktor yang mempengaruhi keterikatan dalam bekerja adalah kepemimpinan transformasional, seorang pemimpin harus bisa mengarahkan dan mengajak karyawannya untuk secara keseluruhan dapat terlibat dalam pekerjaannya dan karyawan dengan keterikatan tinggi terhadap pekerjaannya akan enggan untuk meninggalkan pekerjaannya dan memiliki keinginan untuk tinggal di dalam perusahaan (Kriswanta et al., 2021).

Kepuasan kerja merupakan faktor lain yang dapat mendorong keterikatan kerja. Perasaan positif tentang pekerjaan merupakan salah satu tanda adanya kepuasaan kerja sebaliknya ketidakpuasan ditunjukkan oleh perasaan negatif tentang pekerjaan (Paripurna, I Gede Diatmika; Supartha, I Wayan Gede; Subudi, 2017). Dampak lain dari ketidakpuasaan kerja adalah dengan menunjukan respon pengabaian termasuk didalamnya adalah kemangkiran, keterlambatan ataupun meningkatnya kesalahan yang diperbuat, begitu pula sebaliknya kepuasan kerja akan menunjukkan adanya keterikatan pada pekerjaan. Karyawan yang memiliki keterikatan akan termotivasi dalam bekerja termasuk mau menerima tantangan pekerjaan yang memberi makna bagi dirinya (Sari et al., 2020). Karyawan yang sudah merasa puas dan memiliki keterikatan akan pekerjaannya akan berpengaruh terhadap keinginannya untuk tinggal didalam perusahaan.

Kepuasan kerja dan keterikatan karyawan terhadap perusahaan memiliki peranan penting, dimana kepuasan kerja dapat menurunkan turnover dan memperbaiki kinerja perusahaan. Kepuasan kerja dapat menurunkan intention to stay, karena karyawan yang merasa tidak puas akan memiliki keinginan untuk pindah (Kadek et al., 2015) dan karyawan yang memiliki keterikatan yang tinggi terhadap pekerjaannya akan enggan untuk meninggalkan pekerjaannya dan memiliki keinginan untuk tinggal di dalam perusahaan (Kriswanta et al., 2021).

Niat untuk tinggal didalam perusahaan sangat penting untuk kelangsungan suatu perusahaan, perusahaan akan bisa berkembang dengan memiliki karyawan dengan kompetensi yang unggul dan ditunjang dengan kepemimpinan yang baik. Penelitian ini akan meneliti lebih lanjut tentang kepemimpinan transformasional dan kepuasan kerja terhadap niat untuk tinggal karyawan dengan di mediasi keterikatan kerja.

\section{Metodologi}

\subsection{Pengembangan Model}

\subsubsection{Kepemimpinan Transformasional dan Keterikatan Kerja;}

Kepemimpinan transformasional sangat memegang peranan penting dalam menginspirasi karyawan untuk mendukung pencapaian tujuan perusahaan sekaligus memenuhi kebutuhan dan kesejahteraan diri karyawan. Karyawan yang merasa diperhatikan pemimpin akan merasa terikat dengan pekerjaannya. Karyawan yang

\footnotetext{
“LPPM Universitas Pelita Bangsa" 
berkualitas akan mampu memberikan banyak kontribusi untuk kemajuan perusahaan akan diikat serta diberdayakan oleh perusahaan. Keterikatan kerja (work engagement) merupakan hubungan antara karyawan terhadap organisasi atau perusahaan. Karyawan yang sudah memiliki keterikatan kerja cenderung akan melakukan pekerjaan dengan benar dan peduli terhadap pekerjaannya. Menurut Schaufeli, Salanova, Roma dan Bakker (Wailulu et al., 2019) keterikatan kerja merupakan pikiran positif dan memuaskan yang terkait dengan pekerjaan ditandai munculnya energi dan ketahanan mental saat bekerja, dedikasi dalam wujud keterlibatan-antusiasme-tantangan, dan penyerapan yakni mengacu pada sepenuhnya terkonsentrasi dan memiliki kesulitan untuk melepaskan pekerjaan. Hal ni didukung oleh penelitian sebelumnya (Wisobroto \& Prihatsanti, 2017) yang menghasilkan temuan adanya hubungan positif kepemimpinan transformasional dengan keterikatan kerja dan selaras dengan penelitian lainnya (Wailulu et al., 2019) dengan temuan adanya peran kepemimpinan transformasional dalam mendorong keterikatan kerja

\section{H1 : Kepemimpinan Transformasional berpengaruh terhadap Keterikatan Kerja}

\subsubsection{Kepuasan Kerja dan Keterikatan Kerja}

Kepuasan kerja merupakan sebuah bentuk reaksi sikap kognitif, afektif dan evaluatif emosi positif atau rasa senang dari penilaian seseorang akan pekerjaan atau pengalam kerjanya (Polii, 2015). Kepuasan seseorang berbeda-beda sesuai sistem nilai yang dianut. Kepuasan semakin tinggi manakala apa yang dirasakan sesuai dengan keinginan. Dengan kata lain, kepuasan merupakan perasaan senang atau tidak senang dan atau puas atau tidak puas sesorang dalam bekerja. Kepuasan kerja itu sendiri dapat mempengaruhi pemikiran karyawan untuk meninggalkan organisasi (Polii, 2015). Kepuasan dan ketidakpuasan kerja muncul sebagai bentuk respon karyawan atas segala hal yang berkaitan dengan pekerjaan dan fasilitas yang diterima dari perusahaan yang digunakan untuk menunjang pelaksanaan tugas dan meningkatkan nilai diri karyawan. Leinardo dan Setiawan (2017) menemukan bahwa kepuasan kerja berpengaruh positif terhadap keterikatan kerja. Temuan ini selaras dengan penelitian Paijan dan Astri Rumaharbo (2020) dimana kepuasan lerja bisa meningkatkan leterikatan karyawan terhadap perusahaan.

\section{H2 : Kepuasan kerja berpengaruh terhadap Keterikatan kerja}

\subsubsection{Kepemimpinan Transformasional, Keterikatan Kerja dan Niat untuk Tinggal}

Karyawan merasa nyaman jika pemimpinnya itu baik, peduli, memutuskan, menentukan kebijakan atau peraturan yang tidak merugikan karyawan serta memiliki orientasi visi ke depan terutama tentang pengembangan karyawannya (Kriswanta et al., 2021). Pemimpin harus mampu menciptakan kondisi perusahaan yang nyaman sehingga akan mempengaruhi perilaku karyawan. Karyawan yang nyaman berada di perusahaan tidak akan memiliki keinginan untuk berpindah pekerjaan (Kemie \& Purba, 2019). Karyawan yang memiliki keterikatan dengan pekerjaan atau perusahaan dan merasa diperhatikan oleh pimpinannya akan memiliki niat kuat untuk bertahan di perusahaan (Fauzia \& Marwansyah, 2020; Kemie \& Purba, 2019) meskipun penelitian lain hasilnya berbeda (Kriswanta et al., 2021).

H3 : Kepemimpinan transformasional melalui keterikatan kerja berpengaruh terhadap niat untuk tinggal 


\subsubsection{Kepuasan Kerja, Keterikatan Kerja dan Niat untuk Tinggal}

Salah satu bentuk perilaku kepuasan kerja ditunjukkan dengan adanya keterikatan. Karyawan yang memiliki rasa keterikatan yang tinggi maka akan meningkatkan perilaku umum, salah satunya tetap tinggal di perusahaan. Hal ini berarti bahwa karyawan akan tetap bekerja diperusahaan walaupun ada peluang untuk bekerja ditempat lain. Adanya keterikata akan menimbulkan gairah kerja, bersedia mengorbankan lebih banyak tenaga-waktu demi pekerjaannya, dan lebih proaktif dalam mencapai tujuan pekerjaan (Sari et al., 2020). Semakin tinggi tingkat work engagement karyawan maka semakin rendah tingkat intensi keluar (Rachmatan dan Kubatini, 2018), rendah nya tingkat intensi untuk keluar menunjukan niat untuk tinggal didalam perusahaan tinggi.

H4 : Kepuasan kerja melalui keterikatan kerja berpengaruh terhadap niat untuk tinggal

Tabel 1. Operasionalisasi Variabel

\begin{tabular}{|c|c|c|}
\hline Variabel/ Konsep & Indikator & Skala \\
\hline $\begin{array}{l}\text { Kepemimpinan } \\
\text { Transformasional } \\
\text { (Jufrizen \& Lubis, } \\
\text { 2020) }\end{array}$ & $\begin{array}{ll}\text { 1. Menanamkan rasa bangga } \\
\text { 2. Memberikan perhatian (respec) dan kepercayaan } \\
\text { (trust) } \\
\text { 3. Mengkomunikasikan harapan } \\
\text { 4. Mengekspresikan tujuan dengan cara-cara yang } \\
\text { 5ederhana } \\
\text { 5. Menghargai ide-ide bawahan } \\
\text { 6. Melakukan pemecahan masalah secara cermat } \\
\text { 7. Memberikan perhatian pada pribadi } \\
\text { 8. Memberi nasehat dan pengarahan } \\
\end{array}$ & $1-10$ \\
\hline $\begin{array}{l}\text { Kepuasan Kerja } \\
\text { (Wisnawa \& Dewi, } \\
\text { 2020) }\end{array}$ & $\begin{array}{l}\text { 1. Senang dengan gaji yang diterima } \\
\text { 2. Senang memiliki kesempatan mengerjakan } \\
\text { pekerjaan dengan cara sendiri } \\
\text { 3. Senang adanya peluang belajar keterampilan baru } \\
\text { 4. Senang berhubungan dengan rekan kerja } \\
\text { 5. Senang dengan cara pemimpin menangani } \\
\text { bawahannya }\end{array}$ & $1-10$ \\
\hline $\begin{array}{l}\text { Keterikatan Kerja } \\
\text { (Kemie \& Purba, } \\
\text { 2019) }\end{array}$ & $\begin{array}{l}\text { 1. Memandang pekerjaan sebagai bagian hidup } \\
\text { 2. Tidak dapt melepaskan diri dari pekerjaan } \\
\text { 3. Antusias menerima tugas } \\
\text { 4. Pekerjaan memberikan inspirasi } \\
\text { 5. Pekerjaan terasa menantang } \\
\text { 6. } \\
\end{array}$ & $1-10$ \\
\hline $\begin{array}{l}\text { Niat Untuk } \\
\text { Tinggal } \\
\text { (Surantoro \& } \\
\text { Riyadus Solichin, } \\
\text { 2020) }\end{array}$ & $\begin{array}{l}\text { 1. Tidak pernah berniat/berpikir untuk berhenti } \\
\text { 2. Tidak pernah memikirkan untuk pindah bekerja } \\
\text { pada perusahaan lain } \\
\text { 3. Tidak akan meninggalkan perusahaan } \\
\text { 4. Merasa rugi jika berhenti dari pekerjaan saat ini }\end{array}$ & $1-10$ \\
\hline
\end{tabular}




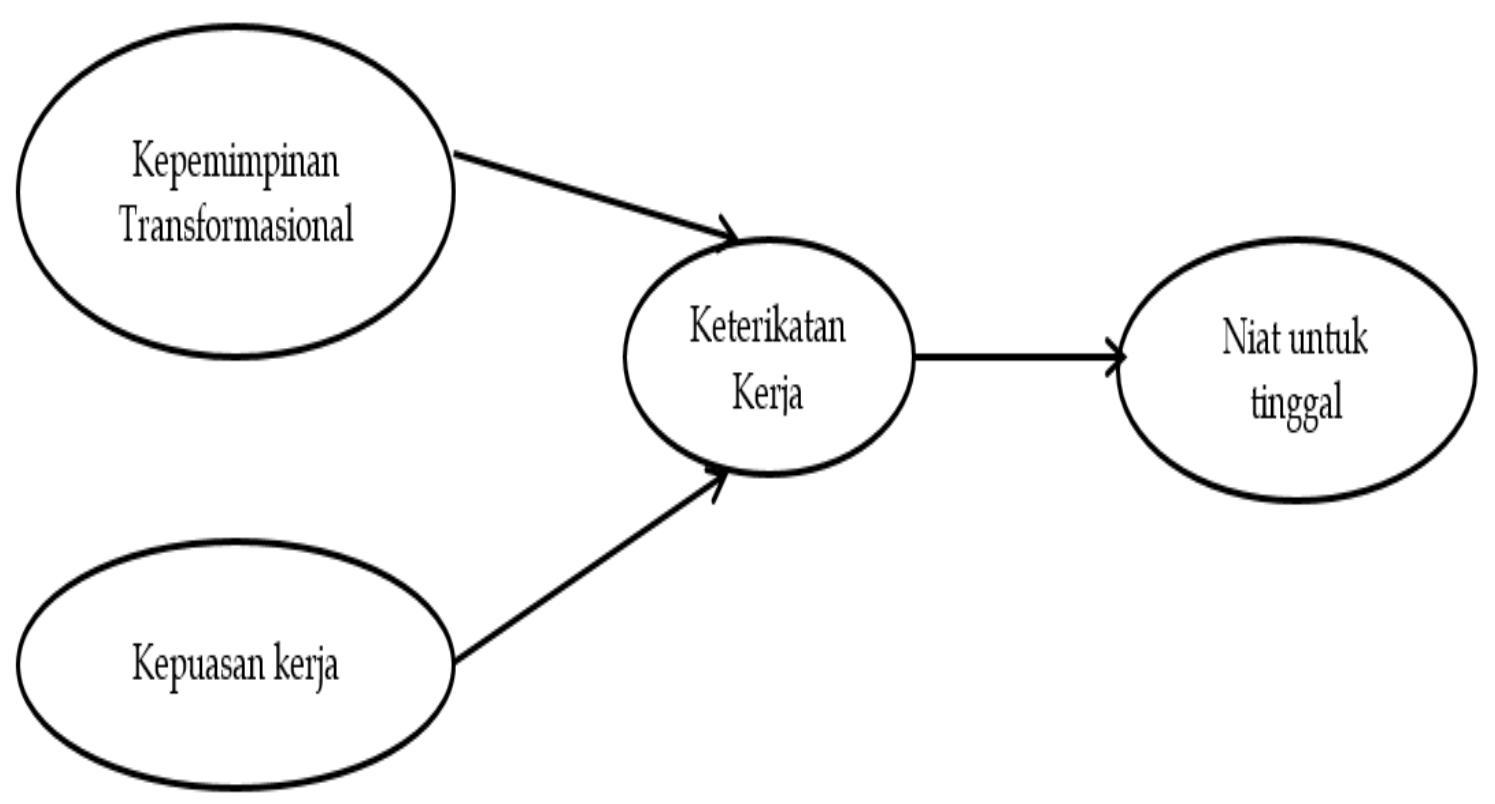

Gambar 1. Desain Penelitian

\subsection{Pengumpulan Data}

Penelitian ini dilakukan pada PT. AW Indonesia di Cikarang, perusahaan ini bergerak pada bidang alat tulis dan menggambar. Populasi penelitian adalah seluruh karyawan PT. AW Indonesia di Cikarang untuk pengambilan data penelitian ini menggunakan teknik simpel random sampling, dimana pengambilan sampel dilakukan secara acak dari populasi yang ada. Dari total populasi yang ada diambil sampel sebanyak 55 karyawan dari 7 Departemen yang ada di perusahaan tersebut

Pengumpulan data penelitian ini menggunakan kuisoner yang disebar melalui Google Form, dimana responden bisa langsung melakukan pengisian dan data dapat langsung ditarik dan diolah oleh peneliti. Pertanyaan dan pernyataan yang terdapat didalam kuisoner tersebut dikukur menggunakan skala bipolar dari 1 - 10 dengan kriteria 1 sangat tidak setuju dan 10 sangat setuju (Mulyanto dan Wulandari, 2010). Kuisoner disebar kepada karyawan yang ada di 7 departemen di perusahan.

\subsection{Metode Analisis}

Metode analisis dengan pendekatan kuantitatif yang bertujuan menganalisis pengaruh kepemimpinan transformasional dan kepuasan kerja terhadap niat untuk tinggal yang dimediasi oleh keterikatan kerja. Analisa datanya menggunakan alat analisis dengan metode PLS (partial least square) dimana pengolahannya dilakukan dengan software Smart PLS 3.0. Langkah analisis meliputi pengujian outer dan inner model(Chin \& Newsted, 1999).

Pengujian outer menggunakan loading outer sebagai bentuk uji validitas dengan cut off $>0,7$ tetapi masih tetap dipertahankan jika nilai loadings outer tidak kurang dari 0,4. Cronbach's Alpha dengan cut off $>0,7$ dan nilai $\rho c$ (composite reliability) dengan cut off 
$>0,8$ digunakan untuk pengujian Reliabilitas. Pengujian inner model sebagai model structural menggunakan R2

dan Estimasi koefisien. Cut off untuk variabel laten endogenous R2> 0,2. Pengujian hubungan jalur dalam model structural menggunakan standar estimasi dengan cut off p-value $<0,05$

\section{Hasil}

Dari kuisoner yang telah disebar didapatkan data penelitian sebanyak 55 responden karyawan PT AW Indonesia di Cikarang

\subsection{Responden}

Data penelitian diperoleh dari 55 responden PT AW Indonesia di Cikarang dengan karakteristik yang dirangkum pada tabel 2 .

Tabel 2. Data Responden

\begin{tabular}{ccc}
\hline \multicolumn{1}{c}{ Variabel } & Jumlah & Persen \\
\hline Jenis Kelamin & 12 & 21,8 \\
- Perempuan & 43 & 78,2 \\
\hline - Laki-laki & & \\
\hline Usia & 21 & 38,2 \\
- Diatas 40 tahun & 28 & 50,9 \\
- Antara 30 - 40 tahun & 6 & 10,9 \\
- Dibawah 30 tahun & & \\
\hline Lama Bekerja & 25 & 45,5 \\
- Diatas 15 tahun & 15 & 27,3 \\
- Antara 10 -15 tahun & 13 & 23,6 \\
- Antara 5 -10 tahun & 2 & 3,6 \\
- Dibawah 5 tahun & & \\
\hline
\end{tabular}

Sumber: Data hasil kuesioner yang diolah, 2021

Tabel 2 menunjukkan data responden yaitu karyawan PT AW Indonesia di Cikarang yang menjadi sampel penelitian sebanyak 55 orang. Sebagian besar responden laki-laki, berusia antara 30 - 40 tahun keatas, dengan masa kerja rata - rata diatas 15 tahun

\subsection{Analisis}

Hasil pengujian outer yang digunakan untuk pengujian validitas dan reliabilitas disajikan pada tabel 3.

Hampir seluruh indikator pada setiap variabel telah valid karena telah lebih besar daripada 0,7. Seluruh variabel juga telah reliabel karena telah memenuhi cut off yang digunakan dalam penelitian ini (cronbach alpha kepemimpinan transformasional 0,986; kepuasan kerja 0,861; keterikatan kerja 0,899 dan niat untuk tinggal 0,933 lebih besar dari 0,7 sedangkan composite reliability kepemimpinan transformasional 0,949; kepuasan kerja 0,905; keterikatan kerja 0,926 dan niat untuk tinggal 0,953 lebih besar daripada 0,8 ). 
Tabel 3. Uji Validitas dan Reliabilitas

\begin{tabular}{|c|c|c|c|c|}
\hline Variabel/Indikator & $\begin{array}{c}\text { Outer } \\
\text { Loading }\end{array}$ & $\begin{array}{c}\text { Crombah } \\
\text { Alpha }\end{array}$ & $\begin{array}{l}\text { Composite } \\
\text { Reliability }\end{array}$ & Kesimpulan \\
\hline $\begin{array}{ll}\text { Kepemimpinan Transformasional } \\
\text { - } & \text { Menanamkan rasa bangga } \\
\text { - } & \text { Memberikan perhatian } \\
& \text { (respec) dan kepercayaan } \\
& \text { (trust) } \\
\text { - } & \text { Mengkomunikasikan } \\
& \text { harapan } \\
\text { - } & \text { Mengekspresikan tujuan } \\
& \text { dengan cara-cara yang } \\
& \text { sederhana } \\
\text { - } & \text { Menghargai ide-ide } \\
& \text { bawahan } \\
\text { - } & \text { Melakukan pemecahan } \\
\text { masalah secara cermat } \\
\text { - Memberikan perhatian pada } \\
\text { pribadi } \\
\text { Memberi nasehat dan } \\
\text { pengarahan }\end{array}$ & $\begin{array}{l}0,793 \\
0,842 \\
0,822\end{array}$ & 0,936 & 0,949 & $\begin{array}{l}\text { Valid } \\
\text { Valid } \\
\text { Valid }\end{array}$ \\
\hline $\begin{aligned} & \text { Kepuasan Kerja } \\
& \text { - } \text { Senang dengan gaji yang } \\
& \text { diterima } \\
& \text { - } \text { Senang memiliki } \\
& \text { kesempatan mengerjakan } \\
& \text { pekerjaan dengan cara } \\
& \text { sendiri } \\
& \text { - } \text { Senang adanya peluang } \\
& \text { belajar keterampilan baru } \\
&-\quad \text { Senang berhubungan } \\
& \text { dengan rekan kerja } \\
& \text { - } \text { Senang dengan cara } \\
& \text { pemimpin menangani } \\
& \text { bawahannya }\end{aligned}$ & $\begin{array}{l}0,909 \\
0,863 \\
0,816\end{array}$ & 0,861 & 0,905 & $\begin{array}{l}\text { Valid } \\
\text { Valid } \\
\text { Valid }\end{array}$ \\
\hline $\begin{aligned} & \text { Keterikatan Kerja } \\
& \text { - } \text { Memandang pekerjaan } \\
& \text { sebagai bagian hidup } \\
& \text { - } \text { Tidak dapt melepaskan diri } \\
& \text { dari pekerjaan } \\
& \text { - } \text { Antusias menerima tugas } \\
& \text { - } \text { Pekerjaan memberikan } \\
& \text { inspirasi } \\
& \text { - } \text { Pekerjaan terasa menantang } \\
& \text { - } \text { Waktu terasa cepat berlalu } \\
& \text { ketika bekerja } \\
&\end{aligned}$ & $\begin{array}{l}0,866 \\
0,885 \\
0,779 \\
0,905 \\
0,782\end{array}$ & 0,899 & 0,926 & $\begin{array}{c}\text { Reliabel } \\
\text { Valid } \\
\text { Valid } \\
\text { Valid } \\
\text { Valid } \\
\text { Valid }\end{array}$ \\
\hline
\end{tabular}




\begin{tabular}{lcccc}
\hline \multicolumn{1}{c}{ Variabel/Indikator } & $\begin{array}{c}\text { Outer } \\
\text { Loading }\end{array}$ & $\begin{array}{c}\text { Crombah } \\
\text { Alpha }\end{array}$ & $\begin{array}{c}\text { Composite } \\
\text { Reliability }\end{array}$ & Kesimpulan \\
\hline $\begin{array}{l}\text { Niat untuk tinggal } \\
\text { - } \begin{array}{l}\text { Tidak pernah berniat atau } \\
\text { memikirkan untuk berhenti }\end{array}\end{array}$ & 0,966 & 0,933 & 0,953 & $\begin{array}{c}\text { Reliabel } \\
\text { Valid }\end{array}$ \\
- $\quad \begin{array}{l}\text { Tidak pernah memikirkan } \\
\text { untuk pindah bekerja pada }\end{array}$ & 0,967 & & & Valid \\
$\quad \begin{array}{l}\text { perusahaan lain } \\
\text { Tidak akan meninggalkan } \\
\text { perusahaan }\end{array}$ & 0,927 & & Valid \\
$\begin{array}{l}\text { Merasa rugi jika berhenti } \\
\text { dari pekerjaan saat ini }\end{array}$ & 0,788 & & Valid \\
\hline Sumber: Hasil Pengolahan, 2021 & & &
\end{tabular}

Tabel 4. R Square

\begin{tabular}{lcc}
\hline \multicolumn{1}{r}{ Endogenous Variabel } & R Square & Kategori \\
\hline $\mathrm{R}^{2}$ & & \\
Keterikatan Kerja & 0,747 & Sangat baik \\
Niat untuk tinggal & 0,285 & baik \\
\hline
\end{tabular}

Sumber: Data Primer yang diolah, 2021

Model dapat diterima karena seluruh variabel endogen memiliki nilai $\mathrm{R}$ square lebih besar dari 0,2. Variabel endogen keterikatan kerja memiliki nilai $\mathrm{R}$ square 0,747 atau dalam kategori yang moderate sedangkan variabel endogen niat untuk tinggal dengan nilai $\mathrm{R}$ square 0,285 dalam kategori baik.

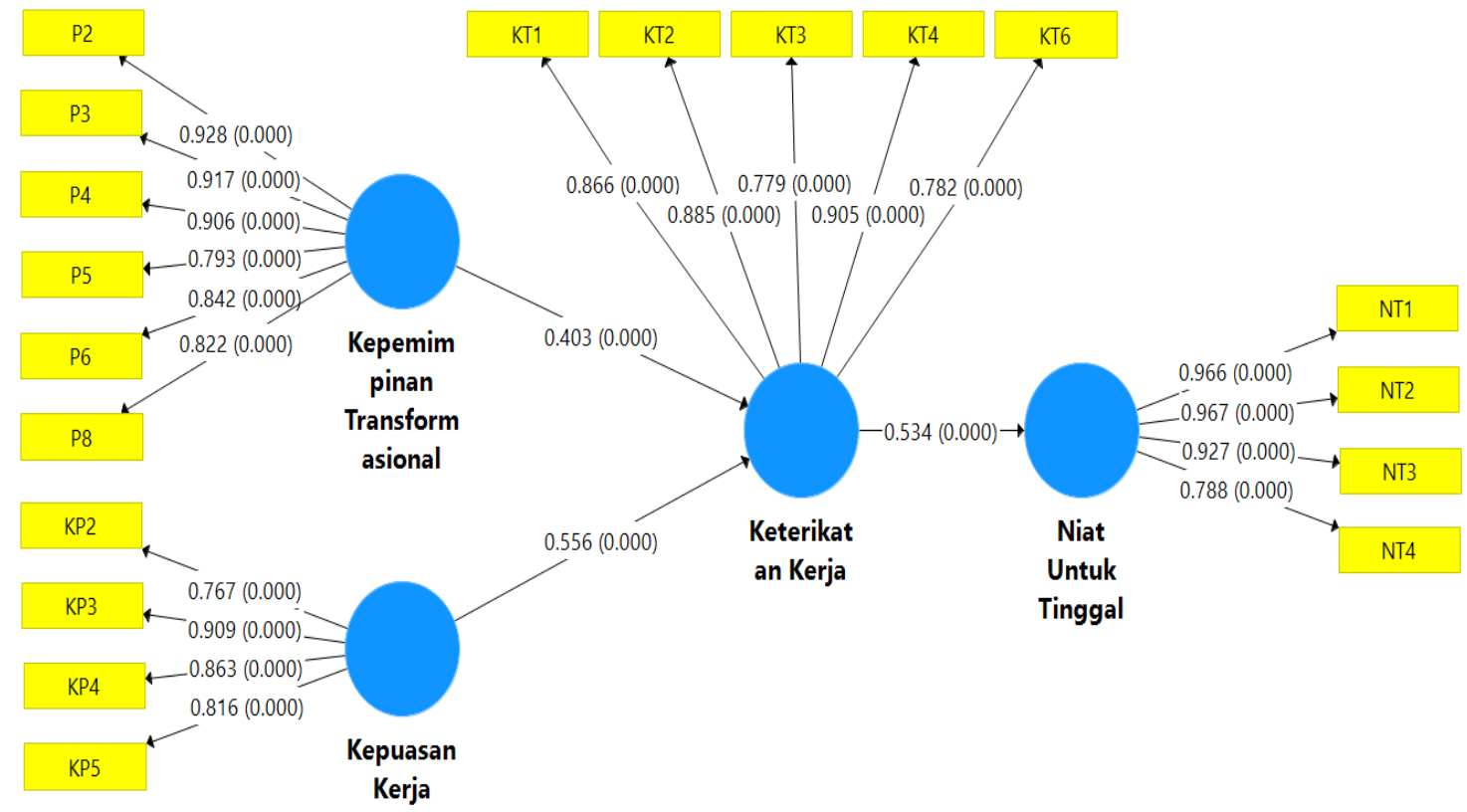

Sumber: Data penelitian diolah, 2021

Gambar 2. Hasil Analisis 
Gambar 2 menunjukkan estimasi dari indikator ke variabel dan keterkaitan antar variabel. Seluruh indikator telah berkontribusi membentuk variabel masing-masing. Indikator P2 merupakan indikator utama pembentuk kepemimpinan transformasional, KP3 sebagai indikator utama Kepuasan kerj, KT4 sebagai indikator utama keterikatan kerja dan NT2 merupakan indikator utama dari niat untuk tinggal.

Tabel 5. Estimasi

\begin{tabular}{|c|c|c|c|c|}
\hline Alur & Jenis & $\begin{array}{c}\text { Std. } \\
\text { Estimates }\end{array}$ & P-Value & Kesimpulan \\
\hline $\begin{array}{l}\text { Kepemimpinan transformasional } \rightarrow \\
\text { Keterikatan kerja }\end{array}$ & Langsung & 0,403 & 0,000 & Signifikan \\
\hline Kepuasan kerja $\rightarrow$ Keterikatan kerja & Langsung & 0,556 & 0,000 & Signifikan \\
\hline $\begin{array}{l}\text { Keterikatan kerja } \rightarrow \text { Niat untuk } \\
\text { tinggal }\end{array}$ & Langsung & 0,534 & 0,000 & Signifikan \\
\hline $\begin{array}{l}\text { Kepemimpinan Transformasional -> } \\
\text { Keterikatan Kerja -> Niat Untuk } \\
\text { Tinggal }\end{array}$ & $\begin{array}{l}\text { Tidak } \\
\text { Langsung }\end{array}$ & 0,215 & 0,007 & Signifikan \\
\hline $\begin{array}{l}\text { Kepuasan Kerja -> Keterikatan Kerja } \\
\text {-> Niat Untuk Tinggal }\end{array}$ & $\begin{array}{l}\text { Tidak } \\
\text { Langsung }\end{array}$ & 0,297 & 0,000 & Signifikan \\
\hline
\end{tabular}

Sumber: Data penelitian yang diolah, 2021

Tabel 5 menunjukkan alur pengaruh antar variabel dalam model. Kepemimpinan transformasional berpengaruh terhadap keterikatan kerja, kepuasan kerja berpengaruh terhadap keterikatan kerja dan keterikatan kerja berpengaruh terhadap niat untuk tinggal.Kepemimpinan transformasional dan kepuasan kerja secara tidak langsung berpengaruh terhadap niat untuk tinggal melalui keterikatan kerja.

\section{Pembahasan}

\subsection{Pengaruh Kepemimpinan Transformasional Terhadap Keterikatan Kerja}

Penelitian menghasilkan temuan bahwa kepemimpinan transformasional yang ada di dalam perusahaan berpengaruh secara positif terhadap keterikatan kerja dengan nilai koefisien sebesar 0,403. Semakin baik kepemimpinan transformasional yang diberikan terhadap karyawan akan membuat karyawan merasa terikat terhadap pekerjaan yang dijalaninya.

Penelitian ini sejalan dengan temuan sebelumnya (Wisobroto \& Prihatsanti, 2017) yang mengemukakan bahwa kepemimpinan transfomasional dapat menumbuhkan dan mempengaruhi keterikatan kerja. Penelitian ini juga sejalan dengan temuan peneliti lain (Wailulu et al., 2019) dimana kepemimpinan transformasional memiliki hubungan langsung dengan keterikatan kerja.

Model kepemimpinan yang digunakan pada perusahaan akan mempengaruhi keterikatan seorang karyawan dalam bekerja, disini kepemimpinan transformasional 
sangat berpengaruh dalam membentuk keterikatan karyawan terhadap pekerjaannya. Hal ini menunjukkan pentingnya bentuk kepemimpinan transformasional untuk mengikat karyawan pada perusahaan.

\subsection{Pengaruh Kepuasan Kerja Terhadap Keterikatan Kerja}

Penelitian ini menghasilkan temuan bahwa keterikatan terhadap pekerjaan memiliki pengaruh secara langsung terhadap niat untuk tinggal dengan nilai koefisien sebesar 0,556. Semakin tinggi kepuasan dirasakan oleh karyawan akan meningkatkan keterikatan karyawan terhadap pekerjaan, dengan kata lain karyawan puas mereka akan terikat dalam pekerjaan.

Penelitian ini sejalan dengan hasil sebelumnya (Polii, 2015) dimana job embeddedness (keterikatan kerja) positif dipengaruhi kepuasan kerja. Hal ini sejalan dengan penelitian lain (Paijan; Rumaharbo, 2020) bahwa kepuasan kerja meningkatkan keterikatan karyawan.

Kepuasan kerja penting untuk ditingkatkan agar karyawan merasa terikat dengan pekerjaannya. Upaya meningkatkan kepuasan kerja dapat dilakukan dengan memberikan gaji yang cukup, kesempatan bekerja sesuai cara masing-masing, peluang belajar hal baru.

\subsection{Pengaruh Kepemimpinan Terhadap Keterikatan Kerja dan Niat untuk Tinggal}

Penelitian ini menghasilkan temuan bahwa kepemimpinan mempengaruhi niat untuk tinggal secara tidak langsung melalui keterikatan kerja sebesar 0,215. Kepemimpinan yang memiliki respect dan perhatian terhadap karyawannya akan mempengaruhi karyawan tersebut untuk tinggal di perusahaan dan ini diperkuat dengan adanya keterikatan kerja karyawan tersebut.

Penelitian ini tidak sejalan dengan yang diungkapan dalam penelitian Kriswanta, dkk (2021) yang menyatakan bahwa kepemimpinan tidak mempengaruhi niat untuk tinggal karyawannya meskipun keterikatan mempengaruhi niat untuk tinggal. Namun penelitian ini sejalan dengan penelitian lainnya dimana kepemimpinan dapat mempengaruhi niat untuk tinggal/bertahan (Fauzia \& Marwansyah, 2020; Kemie \& Purba, 2019).

Kepemimpinan transformasional di AW Indonesia Cikarang sudah baik sehingga dapat membuat karyawan memiliki keterikatan kerja dan berniat untuk tetap ada di perusahan. Pemimpin hendaknya terus berupaya menanamkan rasa bangga, memberikan perhatian (respec) dan kepercayaan (trust), mengkomunikasikan dan mengekspresikan harapan dan tujuan, serta meluangkan waktu untuk memberikan perhatian, nasehat,dan pengarahan kepada karyawannya.

\subsection{Pengaruh Kepuasan Kerja Terhadap Keterikatan Kerja dan Niat untuk Tinggal}

Kepuasan kerja melalui keterikatan kerja secara tidak langsung mempengaruhi niat untuk tinggal sebesar 0,297. Dari penelitian ini dapat dikatakan bahwa kesempatan perusahaan untuk memberikan peluang karyawannya untuk bekerja lebih baik menjadi indicator utama kepuasan karyawannya hal ini diperkuat dengan pekerjaan yang selalu memberi inspirasi karyawan untuk berkembang dapat menumbuhkan keinginan untuk tetap tinggal di perusahan. 
Penelitian ini tidak sejalan dengan apa yang telah dikemukakan Sari (2020) yang menyatakan bahwa kepuasan kerja tidak berpengaruh signifikan terhadap keterikatan kerja dan keterikatan kerja tidak berpengaruh terhadap keinginan untuk tetap tinggal (Intensi keluar). Sedangkan pada Perusahaan AW Indonesia di Cikarang ini kepuasan kerja karyawan berpengaruh terhadap keterikatan kerja dan niat untuk tetap tinggal di perusahaan. Hasil ini mendukung penelitian sebelumnya (Rachmatan dan Kubatini, 2018) dimana kepuasan dapat menghambat keinginan karyawan untuk pindah atau menahan karyawan untuk tinggal sehingga memberikan kepuasan kepada karyawannya menjadi hal yang penting.

\section{Kesimpulan}

Kepemimpinan Transformasional dan Kepuasaan kerja karyawan PT. AW Indonesia dengan adanya mediasi keterikatan kerja berpengaruh secara tidak langsung pada keinginan karyawan untuk tetap tinggal di perusahaan. Kepemimpinan transformasional ini dapat dilihat pada kepemimpinan yang mendapat respek dan kepercayaan terhadap karyawan tergolong tinggi dan karyawan diberikan kesempatan untuk terus dapat berapresiasi dalam bekerja sehingga karyawan tersebut memiliki keinginan untuk tetap tinggal didalam perusahaan. Sedangkan dari hal kepuasan bekerja karyawan PT AW Indonesia di Cikarang merasa puas karena selalu diberikan kesempatan untuk belajar ketrampilan baru, banyaknya kesempatan yang diberikan perusahaan semakin karyawan tersebut nyaman dan berkeinginan untuk tetap tinggal di perusahaan.

Perusahaan agar terus dapat meningkatkan dan mempertahankan kepemimpinannya serta untuk lebih memperhatikan kepuasan karyawan dengan lebih memberikan bebagai kesempatan - kesempatan baru dan lebih memperhatikan kesejahteraan karyawannya. Dan untuk penelitian ini dapat dilanjutkan dengan penelitian - penelitian berikutnya dengan lebih memperbanyak indicator - indicator lainnya sehingga bisa mendapatkan gambaran indicator yang lebih berkontribusi terhadap variabel penelitiannya.

\section{Daftar Pustaka}

Fauzia, N. K., \& Marwansyah. (2020). Pengaruh Employee Engagement terhadap Turnover Intention Studi Kasus PT XYZ Bandung. Jurnal Riset Bisnis Dan Investasi, 6(1), 33-42.

Ghoniyah, N. M. (2011). Peningkatan Kinerja Karyawan Melalui Kepemimpinan, Lingkungan Kerja dan Komitmen. In JDM (Vol. 2, Issue 2). http://journal.unnes.ac.id/nju/index.php/jdm

Jufrizen, J., \& Lubis, A. S. P. (2020). Pengaruh Kepemimpinan Transformasional dan Kepemimpinan Transaksional terhadap Kinerja Pegawai Dengan Locus Of Control Sebagai Variabel Moderating. Maneggio: Jurnal Ilmiah Magister Manajemen, 3(1), 41-59. https:// doi.org/10.30596/maneggio.v3i1.4874

Kadek, N., Citra Dewi, N., \& Subudi, M. (2015). PENGARUH KEPEMIMPINAN TRANSFORMASIONAL TERHADAP KEPUASAN KERJA DAN TURNOVER INTENTION PADA CV. GITA KARYA PERSADA DENPASAR. 4(12), 4219-4244. 
Kemie, S. S., \& Purba, S. D. (2019). EFEK MEDIASI KEPUASAN KERJA PADA PENGARUH KETERIKATAN KERJA DAN MANAJEMEN KARIRTERHADAP KEINGINAN UNTUK TETAP TINGGAL DI DALAM ORGANISASI (Studi Terhadap Para Pengajar di Akademi ATCKR). In Equilibrium: Jurnal EkonomiManajemen-Akuntansi (Vol. 15, Issue 1).

Kriswanta, K., Mulyono, A., Iskandar, H., Haris Pratama, F., Wiji Astuti, D., \& Aulia, A. (2021). Pengaruh Kepemimpinan dan Pengembangan Karir Terhadap Niat untuk Tinggal dengan Keterikatan Kerja sebagai Intervening. MASTER: Jurnal Manajemen Strategik Kewirausahaan, 1(1), 37-46. https://doi.org/10.37366/master.v1i1.135

Lienardo, Sylvia; Setiawan, R. (2017). PENGARUH ORGANIZATIONAL TRUST DAN JOB SATISFACTION TERHADAP EMPLOYEE ENGAGEMENT PADA KARYAWAN PT. BANGUN WISMA SEJAHTERA. Agora, Vol.5 No.

Maulizar;, Musnadi, S., \& Yunus, M. (2012). PENGARUH KEPEMIMPINAN TRANSAKSIONAL DAN TRANSFORMASIONAL TERHADAP KINERJA KARYAWAN BANK SYARIAH MANDIRI CABANG BANDA. Jurnal Manajemen Pascasarjana Universitas Syiah KualaPascasarjana Universitas Syiah Kuala, 1(1), 58-65.

Paijan; Rumaharbo, A. (2020). Pengaruh Pengembangan Karir, Kepemimpinan Transformasional dan Kepuasan Kerja Terhadap Keterikatan Kerja. Jurnal Ilmiah Manajemen Bisnis, 6, 305-323.

Paripurna, I Gede Diatmika; Supartha, I Wayan Gede; Subudi, M. (2017). Pengaruh Kepemimpinan Dan Kepuasan Kerja Terhadap Turnover Intention Serta Dampaknya Terhadap Kinerja Karyawan. E-Jurnal Manajemen Universitas Udayana, 6, 2441-2474.

Polii, L. R. G. (2015). THE ANALYSIS OF JOB EMBEDDEDNESS AND WORK ENVIRONMENT TO JOB SATISFACTION AND TURNOVER INTENTIONS AT SILOAM HOSPITAL MANADO. Jurnal EMBA, 3, 178-190.

Rachmatan, R., \& Kubatini, S. (2018). Hubungan Antara Keterikatan Kerja dengan Intensi Keluar Kerja pada Karyawan Swalayan di Banda Aceh Relationship betweeen Work Engagement and Turnover Intention among Supermarket Employee in Banda Aceh. In Jurnal Psikogenesis (Vol. 6, Issue 1).

Rokhman, W. (2011). ORGANIZATIONAL JUSTICE AS A MEDIATOR FOR TRANSFORMATIONAL LEADERSHIP AND WORK OUTCOMES.

Sari, A. P., Hermawan, A., \& Affandi, M. J. (2020). Pengaruh Kepuasan Kerja dan Keterikatan Karyawan Terhadap Turnover Intention Karyawan (Studi Kasus: Restoran). Jurnal Aplikasi Bisnis Dan Manajemen. https://doi.org/10.17358/jabm.6.2.258

Surantoro, L., \& Riyadus Solichin, M. (2020). Pengaruh Workplace Spirituality dan Person Job Fit Terhadap Intention to Stay Melalui Organizational Commitment sebagai Variabel Intervening (Studi pada Pegawai LAZIS Al Ihsan Jawa Tengah). In Jurnal Ilmiah Mahasiswa Manajemen (Vol. 2, Issue 6). http://journal.stieputrabangsa.ac.id/index.php/jimmba/index

Wailulu, K. N., Dewi, F. I. ., \& Idulfilastri, R. M. (2019). PERAN KEPEMIMPINAN TRAN SFORMASIONAL TERHADAP KETERIKATAN KERJA PADA KARYAWAN MILENIAL DENGAN VARIABEL KOMUNIKASI SEBAGAI MEDIATOR. Jurnal 
Muara Ilmu Sosial, Humaniora, Dan Seni, 3(2), 328. https://doi.org/10.24912/jmishumsen.v3i2.5881

Wisnawa, I. N. A., \& Dewi, A. . S. K. (2020). GAYA KEPEMIMPINAN TRANSFORMASIONAL BERPENGARUH TERHADAP ORGANIZATIONAL CITIZENSHIP BEHAVIOUR DENGAN DIMEDIASI VARIABEL KEPUASAN KERJA. E-Jurnal Manajemen Universitas Udayana, 9(2), 528. https://doi.org/10.24843/ejmunud.2020.v09.i02.p07

Wisobroto, S., \& Prihatsanti, U. (2017). HUBUNGAN ANTARA KEPEMIMPINAN TRANSFORMASIONAL DENGAN KETERIKATAN KERJA PADA PERAWAT RAWAT INAP RUMAH SAKIT ISLAM SULTAN AGUNG SEMARANG (Vol. 6, Issue 1). 